\title{
Aplikasi Website Pengajuan Cuti Karyawan Rumah Sakit Islam Assyifa Sukabumi Berbasis Whatsapp Blast
}

\author{
D A Firmansah ${ }^{1}$, R S Rohman ${ }^{2}$, Y Farlina ${ }^{3}$ \\ Program Studi Sistem Informasi, Universitas Bina Sarana Informatika ${ }^{12}$ \\ Program Studi Sistem Informasi Akuntansi, Universitas Bina Sarana Informatika ${ }^{3}$ \\ Jln. Cemerlang No. 8, Sukakarya, Kota Sukabumi, 43135, Indonesia ${ }^{123}$ \\ dasya.daf@bsi.ac.id ${ }^{1}$,ramdhan.rpe@bsi.ac.id², yusti.yfa@bsi.ac.id*3 \\ diterima: 21 Februari 2020 \\ direvisi: 4 Mei 2020 \\ dipublikasi: 1 September 2020
}

\begin{abstract}
Abstrak
Rumah sakit Islam Assyifa merupakan rumah sakit islam di Sukabumi yang sangat memperhatikan kesejahteraan karyawannya. Salah satu bukti nyata terlaksananya maksud tersebut yaitu berupa pemberian jatah cuti pertahun untuk masing-masing karyawan. Untuk menunjang proses pengajuan cuti ini diperlukan suatu sistem yang baik dengan memanfaatkan website yang ada serta perangkat smartphone yang dimiliki oleh masing-masing karyawan. Hal ini tentunya dapat dilakukan dengan mudah dan lebih cepat karena setiap karyawan yang akan mengajukan cuti hanya cukup mengakses halaman website yang telah ditentukan. Proses pengajuan cuti akan secara otomatis diketahui oleh atasan terkait mengingat notifikasi pengajuan cuti karyawan dapat langsung terkirim pada nomor whatsapp atasan terkait sehingga proses verfikasi pengajuan pun dapat dilakukan secara real time oleh atasan terkait. Dengan adanya sistem tersebut proses rekapitulasi data akan berlangsung lebih cepat mengingat cuti karyawan sangat berpengaruh pada jadwal dinas karyawan masing-masing bagian di RSI Assyifa Sukabumi yang selanjutnya akan berdampak pada pemberian insentif pada masing-masing karyawan.
\end{abstract}

Kata kunci: Pengajuan Cuti; Website; WhatApp

\begin{abstract}
Assyifa Islamic Hospital is an Islamic hospital in Sukabumi that is very concerned about the welfare of its employees. One of the clear evidence of the implementation of this intention is in the form of granting annual leave allowances for each employee. To support the process of filing this leave required a good system by utilizing the existing website and smartphone devices owned by each employee. This of course can be done easily and more quickly because every employee who will apply for leave is only enough to access the website pages that have been determined. The process of submitting leave will be automatically known by the related supervisors, considering that the employee leave submission notification can be sent directly to the supervisor's related number whatsapp so that the verification process of submission can be done in real time by the related supervisor. With this system, the data recapitulation process will take place faster because employee leave is very influential on the employee service schedule of each division in the Sukabumi Assyifa Department, which in turn will have an impact on giving incentives to each employee.
\end{abstract}

Keywords: Filing Leave; Website; WhatsApp

\section{Pendahuluan}

Setiap instansi memiliki peraturan tersendiri untuk setiap karyawannya guna meningkatkan kedisiplinan serta memberikan kenyamanan pada karyawan dalam rangka meningkatkan kualitas dari instansi terkait. Rumah sakit islam Assyifa Sukabumi merupakan instansi swasta yang bergerak dalam bidang jasa pelayanan kesehatan yang sangat memperhatikan kesejahteraan karyawaannya. Salah satu bukti konkretnya yaitu 
berupa pemberian jatah cuti tahunan pada setiap karyawan dengan jumlah dua belas hari dalam setahun untuk masing-masing karyawan.

Cuti adalah keadaan tidak masuk kerja yang diijinkan dalam jangka waktu tertentu. Cuti diberikan dalam rangka usaha menjamin kesegaran jasmani dan rohani[1]. Sebelumnya proses pengajuan cuti dilakukan secara manual dan sering terjadi kendala yang menghambat proses tersebut, mulai dari kesibukan atasan terkait, berkas yang tercecer bahkan ketidakhadiran atasan terkait pada saat pengajuan cuti.

Pengajuan cuti yang telah berlangsung sebelumnya masih dilakukan secara manual karena setiap karyawan yang akan mengajukan cuti harus meminta formulir isian cuti terlebih dahulu pada bagian SDM. Formulir tersebut sangat terbatas jumlahnya sehingga apabila jumlahnya mulai habis maka harus dicetak kembali. Kendala selanjutnya yang sering ditemui yaitu sulitnya meminta tanda tangan pada atasan terkait. Perlu diketahui dalam setiap pengajuan cuti. Karyawan harus mengajukan pada satu bahkan tiga atasan sekaligus sesuai dengan kondisi jabatan dari karyawan tersebut. Hal ini tidak jarang karyawan yang dimaksud tidak ada ditempat, sedang dinas keluar kota atau bahkan libur berdinas.

Disamping memanfaat teknologi website sebagai media utama dalam mengotimalkan sistem pengajuan cuti juga didukung dengan penggunaan layanan pengiriman pesan masal via Whastapp atau yang sering disebut dengan whatsapp blast. Whatsapp Blast sendiri adalah aplikasi pengirim pesan whatsapp secara massal tanpa perlu menyimpan nomor sebelumnya pada kontak pengirim. Whatsapp Blast adalah aplikasi pihak ketiga yang dikembangkan oleh developer[3]. Dengan memanfaatkan website dan fungsi dari whatsapp blast, proses pengajuan cuti serta berbagai macam hal yang berkaitan dengan cuti dapat dilakukan dengan mudah, cepat dan fleksibel mengingat aktivitas tersebut dapat dilakukan pada masing-masing perangkat yang dimiliki oleh setiap karyawan.

\subsection{Aplikasi}

\section{Kajian Pustaka}

Aplikasi merupakan teknologi yang berkembang pesat. Kemajuan teknologi dalam membantu pengolahan data atau informasi yang tersedia dapat berlangsung secara cepat, efisien, dan akurat. Aplikasi dapat mempermudah proses pengerjaan atau penyelesaian suatu persoalan Matematika sehingga hasil penyelesaiannya tidak diragukan lagi nilai kepastiannya[4]. Pengertian aplikasi secara umum adalah alat terapan yang difungsikan secara khusus dan terpadu sesuai kemampuan yang dimilikinya, aplikasi merupakan suatu perangkat komputer yang siap pakai bagi user[5]. Kesimpulannya aplikasi adalah suatu perangkat yang mempunyai fungsi khusus dan membantu menyelesaikan suatu persoalan bagi siapapun yang menggunakannya.

\subsection{Website}

Website adalah kumpulan dari halaman-halaman situs, dimana tempatnya berada didalam world wide web (www) di internet [6]. Website merupakan sebuah komponen yang terdiri dari teks, gambar, suara animasi sehingga menjadi media informasi yang menarik untuk dikunjungi oleh orang lain. Halaman-halaman website tersebut diakses oleh pengguna melalui protokol komunikasi jaringan yang disebut sebagai Hypertext Transfer Protocol (HTTP)[7]. Kesimpulannya website adalah kumpulan dari halaman-halaman situs yang terdiri dari teks, gambar, suara, animasi menarik dan diakses melalui HTTP.

\subsection{HTML}


Hypertext Markup Language HTML) merupakan dokumen text biasa yang mudah untuk dimengerti dibandingkan bahasa pemrograman lainnya. Dan karena itu HTML dapat dibaca lewat platform yang berlainan seperti Windows, UNIX dan lain-lain. Untuk lebih jelasnya HTML adalah suatu script dimana kita bisa menampilkan informasi dan daya kreasi kita lewat internet[6].

\subsection{PHP}

PHP adalah merupakan bahasa pemrograman untuk script web server-side[8]. PHP adalah bahasa scripting yang menyatu dengan HTML dan dijalankan pada server side. Artinya semua sintaks yang kita berikan akan sepenuhnya dijalankan pada server sedangkan yang dikirimkan ke browser hanya hasilnya saja. PHP menyatu dengan bahasa HTML untuk membuat halaman web yang menarik. PHP mampu berjalan diatas beberapa platfrom seperti Windows, Unix serta varian Linux[9].

\subsection{Mysql}

MySQL merupakan software yang tergolong sebagai DBMS (Database Management System) yang bersifat open source[10]. MYSQL adalah sistem manajemen database yang sering digunakan bersama PHP. MySql merupakan aplikasi data server. Perkembangannya disebut juga $S q l$ yang merupakan kepanjangan dari Structured Query Language (SQL)[11]. MySQL adalah salah satu aplikasi DBMS yang sudah cukup banyak digunakan oleh pemrograman aplikasi web. Contoh DBMS lainnya adalah: PostgreSQL (freeware), SQL Server, MS Acces dari Microsof, DB2 dari IBM, Oracle dan Oracle Corp, Dbase, Foxpro, dsb[8]. Kesimpulannya MySQL adalah software atau aplikasi data server yang digunakan sebagai DBMS yang bersifat open source.

\subsection{UML}

Unified Modeling Language (UML) merupakan strandar yang relatif terbuka yang dikontrol oleh Object Management Group (OMG), sebuah konsorsium terbuka yang terdiri dari banyak perusahaan. OMG dibentuk untuk membuat standar-standar yang mendukung interoperabilitas, khusunya interoperabilitas sistem berorientasi objek. OMG mungkin lebih dikenal dengan standar-standar COBRA (Common Object Request Broker Architecture)[12]. Unified Modeling Language (UML) adalah salah satu standar bahasa yang banyak digunakan di dunia industri untuk mendefinisikan requirement, membuat analisis dan desain, serta menggambarkan arsitektur dalam pemrograman berorientasi objek[13]. Kesimpulannya UML adalah bahasa pemodelan yang menspesifikasikan, menggambarkan, membangun, dan dokumentasi dari sistem perangkat lunak dengan pendekatan berorientasi objek.

\subsection{Whatsapp}

WhatsApp merupakan aplikasi pesan lintas platform yang memungkinkan pengguna bertukar pesan tanpa biaya SMS, karena WhatsApp menggunakan paket data internet yang sama untuk email, browsing web, dan lain-lain[14]. WhatsApp adalah aplikasi pesan instan paling populer dibanding layanan pesan instan lain dengan jumlah pengguna tertinggi di dunia. Pengguna WhatsApp dapat memanfaatkan fasilitas mengirim pesan, gambar, video dan video call hingga membuat kelompok diskusi[15][16]. Whatsapp merupakan salah satu media sosial dengan kategori messenger/chatting secara pribadi maupun dalam suatu grup dengan berbagai fitur yang lebih user-friendly sehingga mudah digunakan oleh berbagai kalangan dari yang muda hingga yang tua, fitur-fitur tersebut meliputi chatting (teks, foto, 
video), panggilan telepon, videocall, status/whatsapp story yang lebih ringan dibandingkan dengan media sosial lainnya[17].

\section{Metode Penelitian}

Metode penelitian berisi mengenai tahapan dari penelitian dengan menjelaskan metode pengembangan perangkat lunak dan metode pengumpulan data yang digunakan dalam penelitian.

\subsection{Metode Pengembangan Perangkat Lunak}

Metode yang digunakan dalam pengembangan perangkat lunak menggunakan model waterfall. Menurut Ladjamudin dalam [18] model waterfall terbagi menjadi lima tahapan, yaitu:

1. Penentuan dan analisa spesifikasi

Langkah ini sendiri merupakan analisa terhadap kebutuhan sistem yang akan dibuat, yakni sistem pengajuan cuti. Tahap ini menentukan rencana pengelolaan data, spesifikasi aplikasi bahkan perangkat yang akan digunakan.

2. Desain sistem dan perangkat lunak

Pada tahap ini sendiri dilakukan pembuatan kerangka sistem yang akan dibangun sesuai dengan data yang telah diperoleh sebelum pembuatan sistem yang sebenarnya.

3. Implementasi dan ujicoba unit

Tahapan ini merupakan tahapan nyata dalam mengerjakan suatu sistem. Hal ini berarti bahwa sistem yang sebenarnya telah siap untuk dibuat setelah dilakukannya pembuatan kerangka sistem.

4. Integrasi dan uji coba sistem

Tahapan ini dapat dikatakan sebagai tahapan terakhir dalam pembuatan sebuah sistem. Setelah melakukan analisa, design dan pengkodean maka sistem yang sudah jadi akan digunakan oleh user.

5. Operasi dan Pemeliharaan

Perangkat lunak yang sudah disampaikan kepada user pasti akan mengalami perubahan. Perubahan tersebut bisa karena mengalami kesalahan maupun karena perangkat lunak harus menyesuaikan dengan kondisi yang ada.

\subsection{Metode Pengumpulan Data}

Metode pengumpulan data yang digunakan dalam penelitian meliputi:

1. Observasi

Agar website yang dirancang sesuai dengan kondisi yang ada pada RSI Assyifa Sukabumi, maka perlu dilakuan pengamatan langsung pada instansi tersebut melalui bagian terkait.

2. Wawancara

Untuk memperkuat analisa maka perlu dilakukan wawancara pada bagian yang khusus mengelola proses cuti dalam hal ini wawancara dilakukan pada bagian SDM dan SIMRS rumah sakit.

3. Studi Pustaka

Dalam rangka menunjang terbentuknya sistem yang dimaksud serta setiap pernyataan yang dikutip maka perlu dilakukan pengambilan informasi sebagai bahan rujukan baik dari jurnal maupun media online.

\subsection{Analisa Kebutuhan}

\section{Hasil dan Pembahasan}


Sistem pengajuan cuti secara online ini dilakukan menggunakan website dan dilengkapi dengan pengiriman pesan masal pada whatsapp atau yang biasa dikenal dengan istilah Whatsapp Blast. User yang terlibat langsung pada sistem ini meliputi karyawan dan atasan. Setiap user disarankan untuk memasukan username berupa Nomor Pokok Pegawai (NPP) \& password untuk dapat mengakses halaman kepegawaian.

Setiap user diperkenankan untuk mengelola data pribadi pada fitur yang telah tersedia. Karyawan hanya dapat melakukan pengajuan cuti sesaat setelah mendapatkan jadwal dinas yang telah diinput oleh atasan terkait. Pada saat karyawan mengajukan cuti diwajibkan untuk menentukan jumlah cuti serta tanggal cuti selanjutnya karyawan juga diwajibkan untuk mengisi nama atasan terkait beserta no WA atasan yang aktif selanjutnya pesan notifikasi akan dikirimkan ke no WA atasan yang sudah diinputkan. Selanjutnya atasan akan melakukan konfirmasi terkait diterima atau tidak nya pengajuan tersebut. Jika pengajuan cuti diterima maka secara otomatis data pada jadwal dinas akan berubah menjadi C (Cuti) lengkap dengan warna yang telah ditentukan. Namun jika pengajuan cuti ditolak maka secara otomatis cuti ditolak dan data pada jadwal dinas tidak akan mengalami perubahan.

Berikut merupakan rincian hak akses untuk masing-masing user:

1. Atasan Terkait

a. Atasan dapat Login dengan username berupa NPP (Nomor Pokok Pegawai) dan password yang telah disesuaikan.

b. Menginput jadwal dinas masing-masing karyawan yang menjadi bawahannya sesuai dengan kondisi yang ada baik terkait bulan, bagian maupun kategori jadwal dinas dari setiap karyawan. Adapun jadwal dinas yang berlaku meliputi: $\mathrm{P}$ (pagi), $\mathrm{S}$ (Siang), M (Malam) dan L (Libur). Semua jadwal dinas tersebut diatas akan terupdate secara otomatis menjadi C (Cuti) pada setiap jadwal karyawan yang telah mengajukan cuti apabila atasan terkait menyetujui pengajuan cuti karyawan yang bersangkutan. Perlu diketahui dalam proses pengajuan cuti tersebut tidak hanya dilakukan pada satu orang atasan saja melainkan dua atau lebih atasan terkait. Hal ini disesuaikan dengan kondisi struktural yang berlaku di RSI Assyifa Sukabumi. Namun apabila atasan menolak pengajuan cuti karyawan maka karyawan tidak berhak mendapatkan cuti dihari yang diinginkan dan jadwal dinas akan tidak akan mengalami perubahan. Kondisi seperti ini biasanya disebabkan oleh beberapa permasalahan. Salah satu diantaranya membludaknya pasien yang ingin dilayani, adanya pertemuan dadakan ataupun hal beberapa hal lain yang tidak memungkinkan cuti yang diajukan dapat disetujui.

c. Atasan dapat mengedit maupun menghapus data jadwal dinas bawahannya.

d. Atasan dapat melakukan verifikasi pengajuan cuti karyawan dengan kondisi diterima ataupun ditolak.

e. Rekap data jadwal dinas dan cuti. Pada tahap ini atasan dapat merekap data jadwal dinas yang sudah diinput baik perorangan maupun semua karyawan yang menjadi bawahannya. Tidak hanya itu, atasan pun dapat merekap data berdasarkan bulan baik beberapa bulan kedepan maupun beberapa bulan kebelakang.

f. Setelah semua aktivitas dilakukan atasan dapat logout dari sistem.

2. Karyawan

a. Login dengan username berupa NPP (nomor Pokok Wajib Pegawai) dan password.

b. Melihat jadwal dinas sesuai akun yang dimiliki. Pada tahap ini karyawan dapat melihat jadwal dinas yang sudah diinput sebelumnya oleh atasan terkait. Pada jadwal dinas juga akan tercantum berapa banyak sisa cuti yang dapat diambil oleh karyawan yang bersangkutan. 
c. Karyawan dapat mengajukan cuti sesuai kondisi yang diinginkan.

d. Melihat status konfirmasi cuti dari atasan. Pada tahap ini karyawan dapat melakukan pengecekan secara langsung terkait informasi status pengajuan cuti dari masingmasing atasan terkait.

e. Setelah semua aktivitas dilakukan karyawan dapat logout dari sistem.

\subsection{Use case Diagram}

Use case diagram merupakan titik awal yang baik dalam memahami dan menganalisis kebutuhan sistem pada saat perancangan. Use case diagram dapat digunakan untuk menentukan kebutuhan apa saja yang diperlukan dari suatu sistem[19]. Gambar 1 berikut merupakan use case diagram karyawan dan atasan terkait:

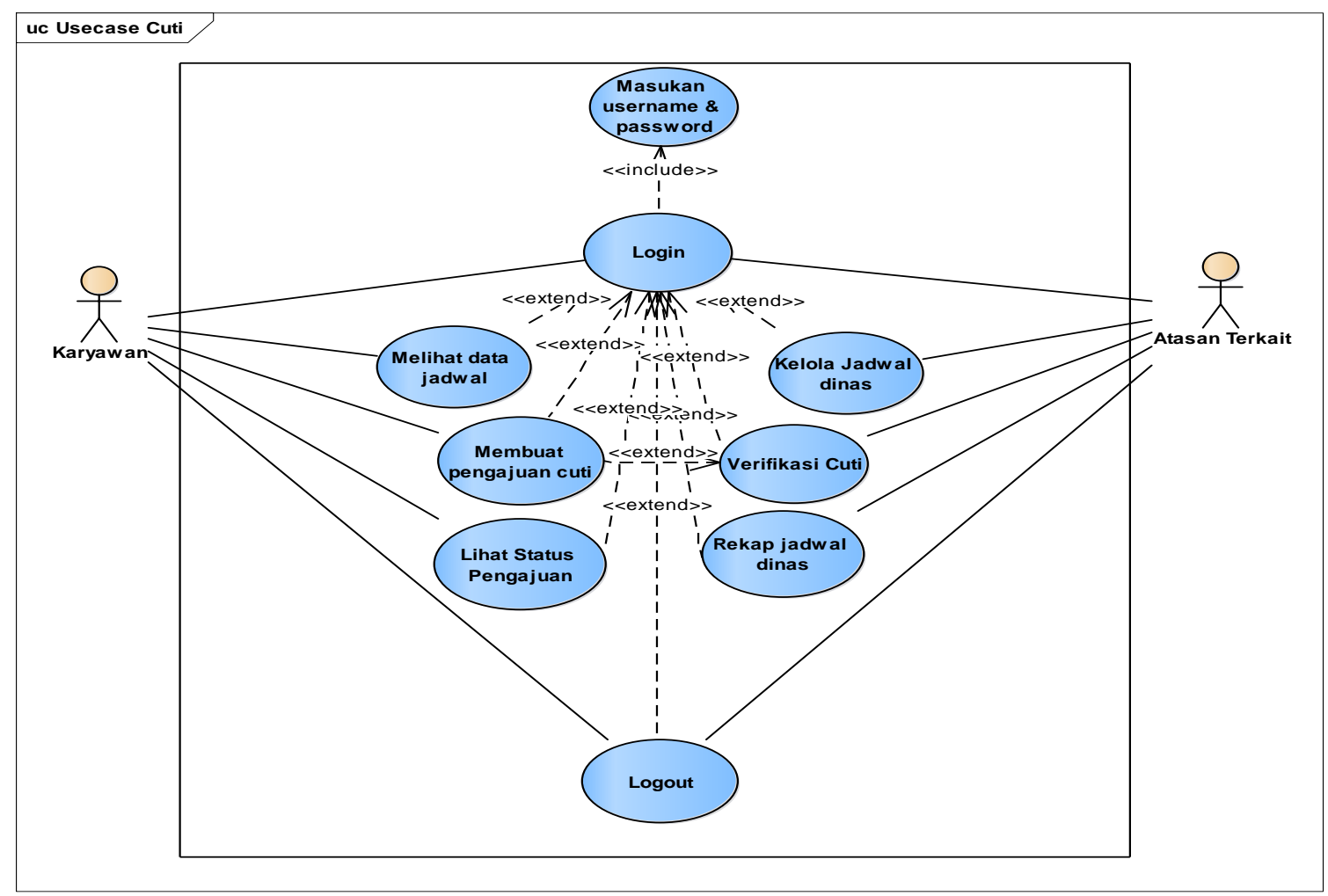

Gambar 1. Use case Diagram karyawan dan atasan terkait

Karyawan dan atasan melakukan login pada halaman yang sama namun diberikan hak akses yang berbeda dengan perbandingan status sebagai kepala atau user. Karyawan diberikan hak akses dengan username dan password untuk dapat mengakses halaman jadwal dinas, pengajuan cuti serta melihat status pengajuan cuti, apakah pengajuan tersebut diterima atau ditolak oleh atasan terkait. Atasan terkait memiliki akses lebih tinggi dari karyawan, karena atasan terkait dapat melakukan pengecekan terikat data karyawan yang menjadi bawahannya. Seperti mengelola jadwal dinas, melakukan verifikasi cuti karyawan bahkan melakukan rekapitulasi jadwal dinas.

\subsection{Activity Diagram}

Secara umum activity diagram merupakan gambaran alur dari suatu sistem yang dibuat, sehingga pengguna mengerti kegunaan sistem yang akan dibangun[20].

1. Activity Diagram Pengajuan Cuti 


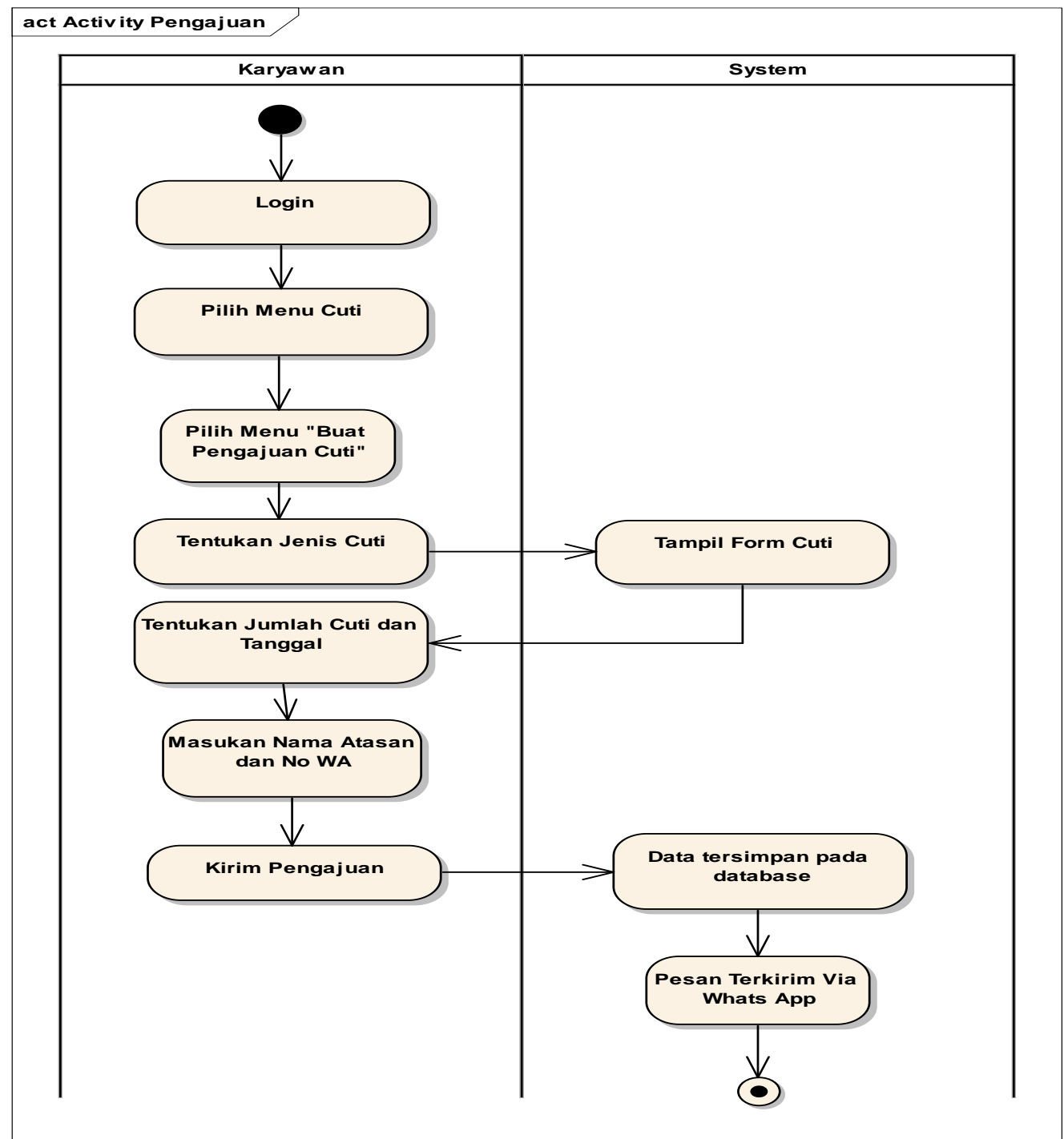

Gambar.2 Activity Diagram Pengajuan Cuti

Gambar 2 merujuk pada proses pengajuan cuti dilakukan langsung melalui halaman website. Bagi karyawan yang ingin mengajukan cuti, karyawan tersebut cukup membuka halaman kepegawaian dengan menggunakan akun pribadi dengan username berupa NPP (Nomor Pokok Pegawai) dan password. Selanjutkan karyawan melakukan pengajuan cuti pada halaman cuti. Karyawan memiliki hak untuk memilih jenis cuti, tanggal cuti dan jumlah cuti. Setelah karyawan menentukan kategori cuti selanjutnya karyawan memilih jumlah atasan sesuai dengan kondisinya lengkap dengan nomor whatsapp dari atasan yang dituju. Selanjutnya pengajuan akan secara otomatis terkirim melalui whatsapp atasan disertai dengan link verifikasi sehingga atasan yang menerima pesan tersebut dapat langsung memverifikasi apakah pengajuan cuti karyawan yang bersangkutan diterima atau ditolak.

2. Activity Diagram Konfirmasi Cuti 


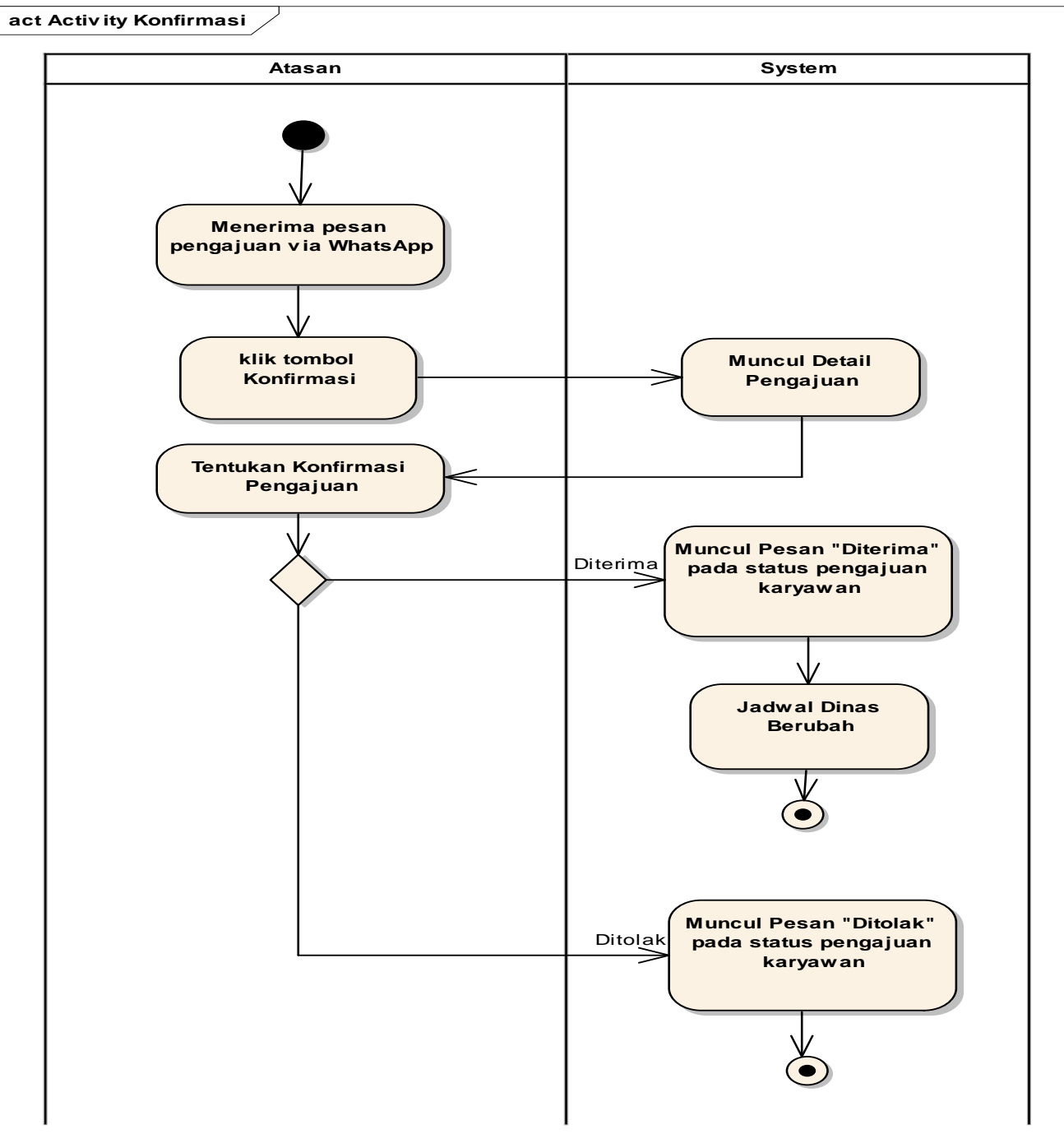

Gambar 3. Activity Diagram Konfirmasi Cuti

Setelah proses pengajuan cuti berhasil dilakukan selanjutnya pesan akan terkirim otomatis ke whatsapp atasan terkait. Pesan tersebut dilengkapi dengan link untuk masuk ke halaman verifikasi cuti. Pada halaman verfikasi cuti, atasan dapat melihat rincian pengajuan cuti dari karyawan terkait. Selanjutnya atasan disarankan mengklik tombol konfirmasi lalu atasan dapat menentukan konfirmasi diterima atau ditolak. Setelah itu maka sistem akan memunculkan pesan bahwa pengajuan sudah diproses. Jika pengajuan data diterima maka data akan otomatis tersimpan pada database.

\subsection{User Interface}

1. Karyawan

Berikut merupakan halaman karyawan:

a. Halaman login karyawan 


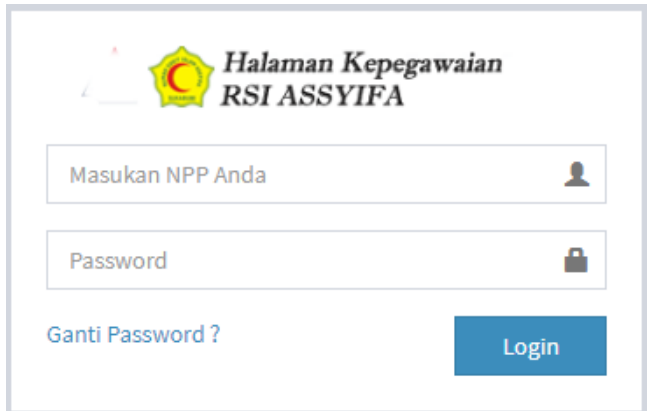

Gambar 4. Halaman Login

Gambar 4 merupakan antarmuka halaman login untuk setiap karyawan dan atasan. Karyawan dan atasan memiliki hak akses masing-masing. Username berupa NPP (Nomor Pokok Pegawai) dan password standar NPP. Password dapat diubah oleh setiap user sesuai dengan keinginan masing-masing.

b. Halaman Pengajuan Cuti Karyawan

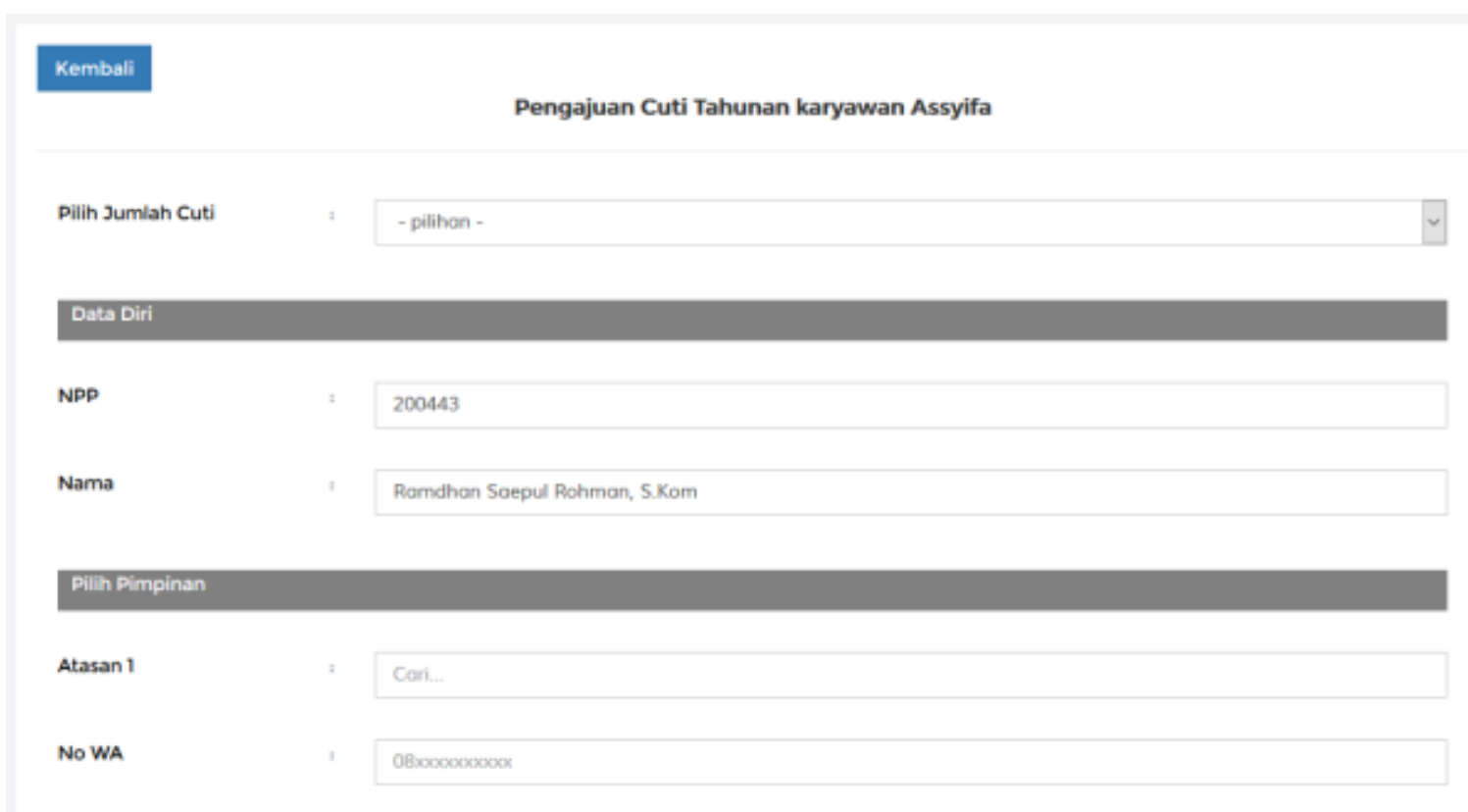

Gambar 5. Halaman Pengajuan Cuti

Gambar 5 merupakan antarmuka halaman pengajuan cuti untuk karyawan. Pada halaman ini berisikan beberapa poin yang harus diisi oleh karyawan yang akan mengajukan cuti, seperti menentukan jumlah cuti, tanggal cuti, dan atasan terkait yang dituju disertai dengan nomor WA atasan.

c. Halaman Status Pengajuan 


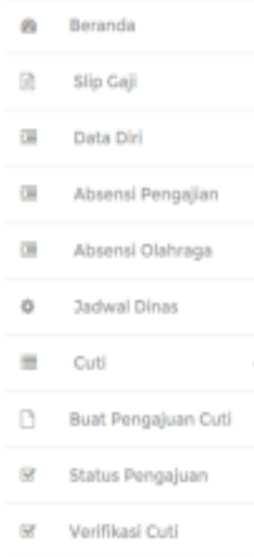

Hame , Status Pengoivon Can

Status Pengajuan Cuti Karyawan

RSI Assyifa Sukabumi

Bulan : December 2019

NPP : 200443

Nama : Ramdhan Saepul Rohman, 5.Kom

\begin{tabular}{|c|c|c|c|c|c|c|c|}
\hline No. & Tgl & $3 a m$ & Jenis cuti & Tanopal Cuti & Lama & Atasan & Status \\
\hline 1 & $11 / 2 / 2019$ & cosco & Cut Tahunan & $01 / 12 / 2012$ & IMari & Dansya Arief Firmansyah,S.Jom & Narrumggy \\
\hline
\end{tabular}

Gambar 6. Halaman Status Pengajuan

Gambar 6 halaman status pengajuan akan menampilkan informasi terkait status pengajuan cuti karyawan pada masing-masing atasan. Halaman ini berisi rincian pengajuan cuti karyawan baik jam dan tanggal pengajuan, tanggal cuti, lama cuti, atasan terkait bahkan status verifikasi dari atasan yang dituju. Adapun status yang dimaksud berupa menunggu, diterima dan ditolak.

d. Halaman Jadwal Dinas Karyawan

\section{Kepegawaian}

RSI ASSYIFA

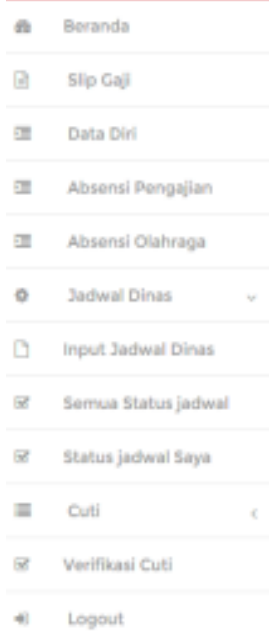

Homse, Absemsi Clahraga

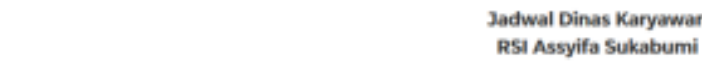

Bulan : December 2019

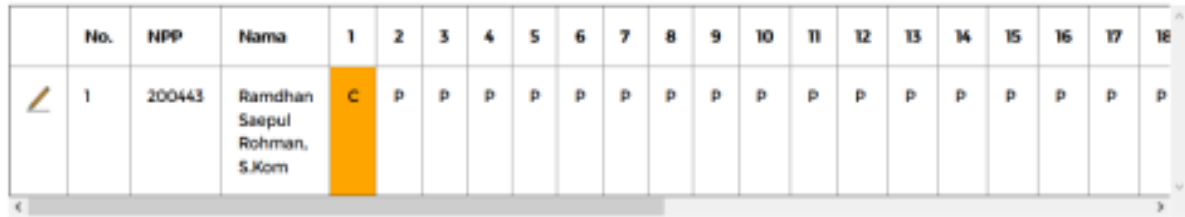

ceterange:

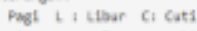

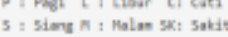

Gambar 7. Halaman Jadwal Dinas Karyawan

Pada gambar 7 halaman jadwal dinas karyawan berisi data jadwal dinas karyawan selama satu bulan mulai dari tanggal 1 sampai dengan tanggal berakhirnya bulan tersebut. Hal ini dilakukan agar karyawan lebih mudah untuk mengakses jadwal dinas mereka masing-masing.

2. Atasan

a. Halaman notifikasi via WhatsApp 


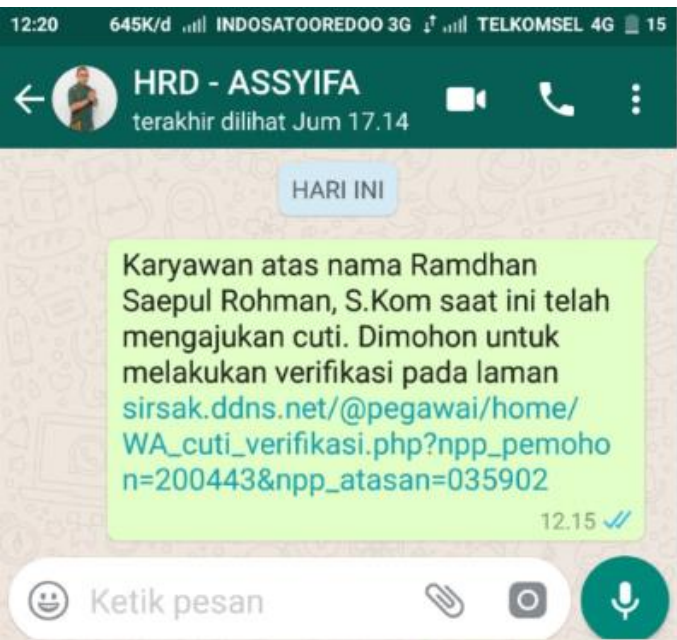

Gambar 8. Halaman notifikasi via WhatsApp

Gambar 8 merupakan salah satu contoh pesan otomatis yang dikirimkan langsung dari website ke nomor WA atasan sesaat setelah karyawan mengajukan cuti.

b. Halaman konfirmasi via mobile
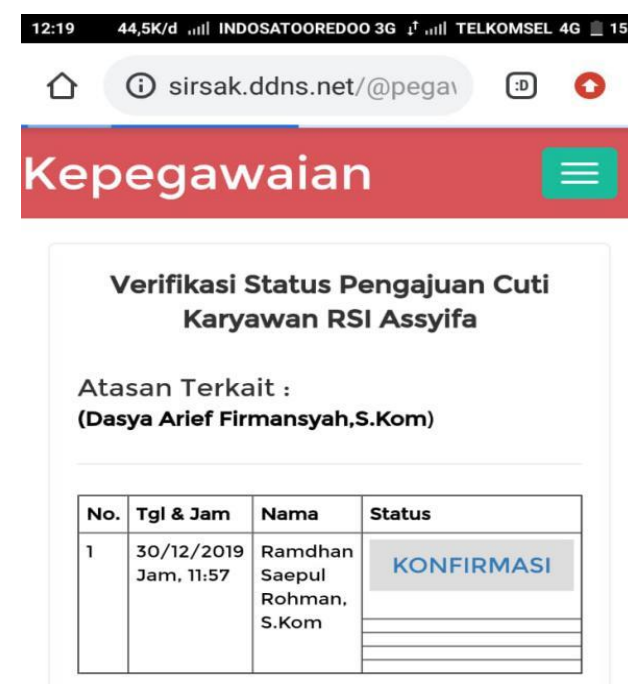

Developed by SIMRS RSI ASSYIFA

(c) 2019 RSI Asyyifa Sukabumi.

All right Reserved

Gambar 9. Halaman konfirmasi via mobile

Gambar 9 merupakan halaman yang akan muncul setelah atasan menglik link yang telah diterima melalui pesan WhatsApp.

c. Halaman detail konfirmasi 

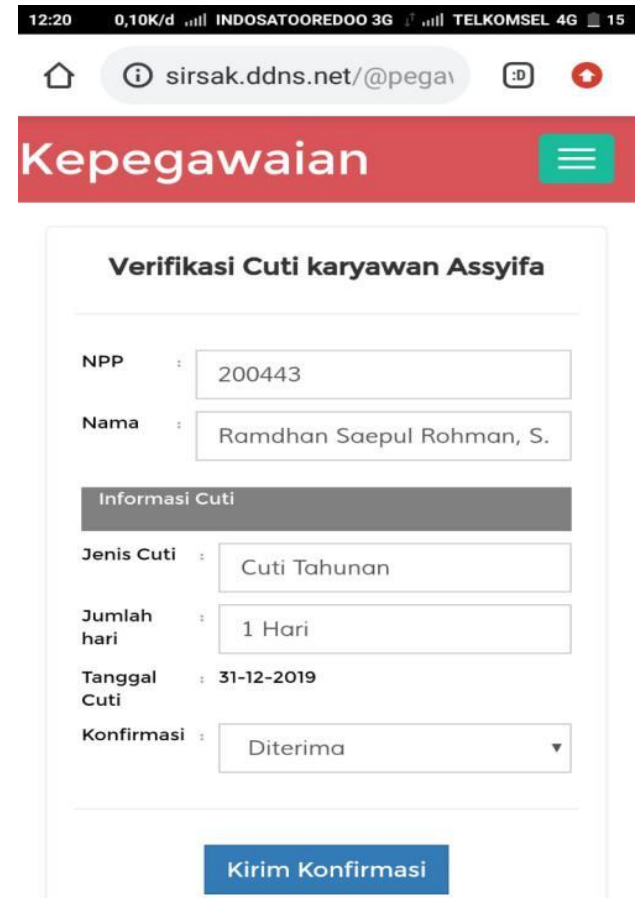

Gambar 10. Halaman detail konfirmasi

Gambar 10 halaman detail konfirmasi merupakan halaman yang muncul setelah atasan mengklik tombol konfirmasi pada tampilan sebelumnya. Pada halaman ini atasan diberikan hak akses untuk menentukan konfirmasi terkait pengajuan cuti karyawan. Apakah pengajuan cuti tersebut diterima atau ditolak.

d. Halaman kelola jadwal dinas

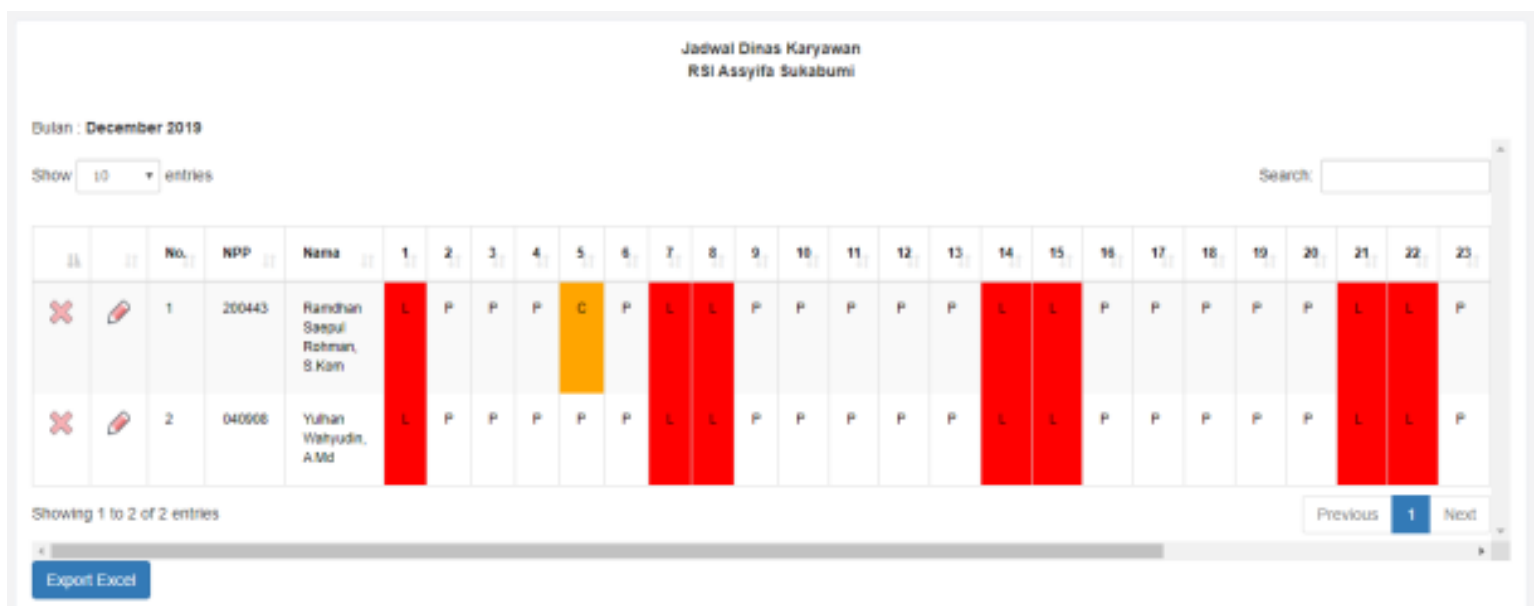

Gambar 11. Halaman kelola jadwal dinas

Gambar 11 merupakan halaman untuk mengedit jadwal dinas. Halaman ini hanya dapat diakses oleh atasan terkait apabila atasan tersebut ingin mengubah data jadwal dinas karyawan yang menjadi bawahannya.

e. Halaman input jadwal 


\section{Kepegawaian}

Home, Penjodwolion Hation , December 2019 , RUANGAN GAWAT DARURAT

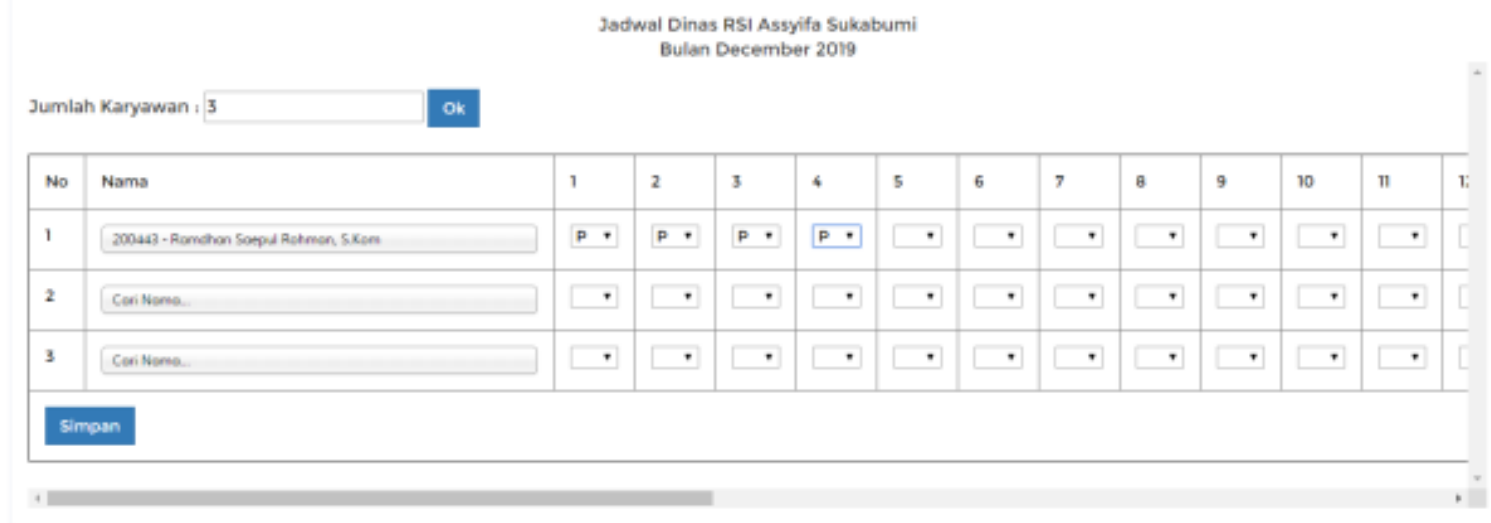

Gambar 12. Halaman input jadwal

Gambar 12 merupakan halaman untuk menginput jadwal dinas. Halaman ini hanya dapat diakses oleh atasan terkait apabila atasan tersebut akan membuat jadwal dinas baru.

\section{Kesimpulan}

Cuti karyawan merupakan salah satu bentuk kebijakan dari suatu instansi dalam rangka memberikan kenyamanan pada karyawan. Proses cuti tentunya akan mempengaruhi aktivitas pada sistem yang lain sehingga diperlukan sistem yang dapat memfasilitasi serta memonitor proses cuti tersebut sehingga dapat mempermudah dan meminimalisir segala jenis kendala yang ada. Dengan adanya sistem ini maka proses pengajuan, verifikasi cuti serta rekapitulasi data dapat dilakukan lebih optimal. Guna meningkatkan kualitas serta kinerja dari aplikasi yang sudah dibuat maka perlu dilakukan pengembangan untuk kedepannya baik dari sisi veris kode yang digunakan, tingkat kecepatan saat digunakan bahkan pada fitur aplikasi itu sendiri sehingga dapat lebih kompatibel dengan berbagai macam platform maupun device yang digunakan.

\section{Ucapan Terima Kasih}

Kami ucapkan terima kasih kepada pihak Rumah Sakit Islam Assyifa Sukabumi yang telah memberikan kami izin dan mendukung dalam proses penelitian ini.

\section{Daftar Pustaka}

[1] Rohendi, K., Informasi, S., Informasi, S., Perhubungan, D., \& Sumatera, K. (n.d.). Jurnal TEKNOIF ISSN: 2338-2724 SISTEM INFORMASI PENGAJUAN CUTI PEGAWAI DINAS Vol. 3 No. 2 Oktober 2015 Jurnal TEKNOIF ISSN: 2338-2724. 3(2).

[2] Nurlatifah, A., Widowati, I. S., \& Riskiana, R. R. (2019). Implementasi Webqual 4.0 Untuk Pembangunan Aplikasi Pengukuran Kualitas Website (WebQTools), 6(2), 9015-9029.

[3] Wawin. (2019, November 28). WhatsApp Marketing. Retrieved January 20, 2020, from Maketers: https://maketers.com/perbedaan-wa-blast-dan-whatsapp-broadcast/

[4] Fitria, S. F., Harahap, E., Badruzzaman, F., Fajar, Y., \& Darmawan, D. (2018). Aplikasi Rata-Rata Data Tunggal. In Seminar Nasional Pendidikan Matematika Ahmad Dahlan 2018 ISSN: 2407-7496 (pp. 145-150).

[5] Siregar, H. F., Siregar, Y. H., \& Melani. (2019). Perancangan Aplikasi Komik Hadist 
Berbasis Multimedia. Jurnal Teknologi Informasi, 2(2), 113-121. https://doi.org/10.36294/jurti.v2i2.425

[6] Kahamdany, H., Kusuma, D. P. D., \& Osmond, A. B. (2018). Pengembangan Motif Karang Jenis Leptoseris Papyracea Pada Aplikasi Batik Berbasis Web Development of Leptoseris Papyracea Type Coral Motif on Web- Based Applications. In eproceeding of engineering (Vol. 5, pp. 1065-1071).

[7] Putri, F. E., Rahmansyah, N., \& Ariandi, V. (2018). Perancangan Sistem Pendukung Keputusan Menggunakan Metode Simple Multi Attribute Rating Technique (SMART) Berbasis Web (Studi Kasus: LPK Hinomaru Padang). Majalah Ilmiah, 25(1), 24-36.

[8] Putra, H. N. (2019). Rancangan Sistem Informasi Data Pasien Puskesmas Pengambiran Kota Padang Menggunakan Bahasa Pemrograman Php Dan Database Mysql. SINKRON, 2(2), 93-99.

[9] Kusuma, S. F., \& Perdananto, B. R. (2016). Perancangan dan pembuatan aplikasi administrasi balita pada posyandu melati rt.12 rw.02 kediri berbasis web. JURNAL INDEKS: ILMU PENGETAHUAN DAN TEKNOLOGI TERINTEGRASI, 01 No 01, $36-45$.

[10] Santoso, \& Nurmalina, R. (2017). Perencanaan dan Pengembangan Aplikasi Absensi Mahasiswa Menggunakan Smart Card Guna Pengembangan Kampus Cerdas (Studi Kasus Politeknik Negeri Tanah Laut). Jurnal Integrasi, 9(1), 84-91.

[11] Novendri, M. S., Saputra, A., \& Firman, C. E. (2019). APLIKASI INVENTARIS BARANG PADA MTS NURUL ISLAM DUMAI MENGGUNAKAN PHP DAN MYSQL. Lentera Dumai, 10(2), 46-57.

[12] Puspitasari, D. (2015). Rancang bangun sistem informasi koperasi simpan pinjam karyawan berbasis web. Jurnal Piral Nusa Mandiri, XI (2), 186-196.

[13] Samsudin, M., Abdurahman, M., \& Abdullah, M. H. (2019). Sistem Informasi Pengkreditan Nasabah Pada Koperasi Simpan Pinjam Sejahtera Baru Kota Ternate Berbasis Web. Jurnal Ilmiah ILKOMINFO, 2(1), 11-23.

[14] Wulandari, A. (2016). Penggunaan Jargon oleh Komunitas Chatting Whatsapp Grup. Transformatika, 12(2), 60-72.

[15] Ekadinata, N., \& Widyandana, D. (2017). Promosi kesehatan menggunakan gambar dan teks dalam aplikasi WhatsApp pada kader posbindu. Berita Kedokteran Masyarakat, 33(11), 547. https://doi.org/10.22146/bkm.26070

[16] Anwar, N., \& Riadi, I. (2017). Analisis Investigasi Forensik WhatsApp Messanger Smartphone Terhadap WhatsApp Berbasis Web. Jurnal Ilmiah Teknik Elektro Komputer Dan Informatika, 3(1), 1. https://doi.org/10.26555/jiteki.v3i1.6643

[17] Ningrum, N. A. P., \& Pramonojati, T. A. (2019). Pengaruh Penggunaan Aplikasi Whatsapp Terhadap Efektivitas Komunikasi Organisasi Di Lingkungan Pegawai Dinas Pariwisata Diy. ISSN: 2355-9357 e-Proceeding of Management (Vol. 6, pp. 1680-1690).

[18] Rohman, R. S., Ermawati, E., Farlina, Y., \& Syabaniah, R. N. (2018). Rancang Bangun Web E-Learning Untuk Pengelolaan Mata Pelajaran Tik Pada Smpit, 6(1), 85-90.

[19] Nardi, J. (n.d.). Aplikasi Kuis Dharma Online Pada Yayasan Cakrawala Dharma Indonesia Menggunakan Linear Congruent Method (LCM) Berbasis Android, 1(2019), 49-55.

[20] Susila, I. A., Taufiq, R., Studi, P., Informatika, T., Teknik, F., \& Tangerang, U. M. (n.d.). Penerapan Metode Analytical Heirarchy Process (Ahp) Dalam Sistem 
Pendukung Keputusan (Spk) Pemensiunan Pada Badan Kepegawaian Dan Pengembangan Sumber Daya Manusia, (2017), 499-506. 